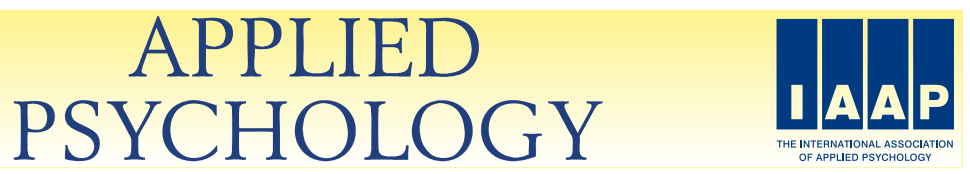

APPLIED PSYCHOLOGY: AN INTERNATIONAL REVIEW, 2013, 62 (1), 157-181 doi: 10.1111/j.1464-0597.2012.00524.x

\title{
A Longitudinal Study of Age-Related Differences in Reactions to Psychological Contract Breach
}

\author{
P. Matthijs Bal* \\ $V U$ University Amsterdam, The Netherlands \\ Annet H. De Lange \\ Radboud University Nijmegen, The Netherlands \\ Paul G.W. Jansen \\ VU University Amsterdam, The Netherlands \\ Mandy E.G. Van Der Velde \\ Utrecht University, The Netherlands
}

\begin{abstract}
The current paper investigated age-related differences in the relations of psychological contract breach with work outcomes over time. Based on affective events theory, we expected job satisfaction to mediate the longitudinal relationship of contract breach with changes in job performance. Moreover, based on socio-emotional selectivity theory, it was predicted that reactions to contract breach on job satisfaction and job performance would be stronger among younger workers than older workers. This two-wave panel study among 240 employees investigated interactions of age with psychological contract breach in relation to changes in job satisfaction and job performance over time. Moderated structural equation modeling showed that job satisfaction partially mediated the longitudinal relationships between contract breach and job performance. Moreover, the analyses supported socio-emotional selectivity theory; older workers reacted less intensely to psychological contract breach towards job satisfaction and job performance, indicating a general decreased responsiveness of older workers towards the psychological contract. It is concluded that age plays an important role in how contract breaches relate to changes in work outcomes over time.
\end{abstract}

\section{INTRODUCTION}

The proportion of older workers relative to younger workers is growing rapidly in North America and Europe (De Lange, Taris, Jansen, Kompier, Houtman, \& Bongers, 2010). The baby boom generation is currently entering

\footnotetext{
* Address for correspondence: Matthijs Bal, VU University Amsterdam, Management \& Organization, De Boelelaan 1105, 1081 HV Amsterdam, The Netherlands. Email: p.m.bal@vu.nl
} 
the second half of their career and birth rates have decreased over recent decades, resulting in a workforce that will increasingly be composed of older workers. Therefore, organisations will have to put more effort into the retention as well as the motivation of older workers. Consequently, psychological contracts, defined as the mutual obligations between an employee and the organisation, as perceived by the employee (Rousseau, 1995), will have to be tailored to the needs and preferences of older workers (Kooij, De Lange, Jansen, \& Dikkers, 2008). Parallel with these demographic trends, research on the role of age in psychological contracts has increased substantially over recent years (Bal, De Lange, Jansen, \& Van der Velde, 2008; Bal, Jansen, Van der Velde, De Lange, \& Rousseau, 2010; Bellou, 2009; Ng \& Feldman, 2009). The main focus in these studies has been on employees' perceptions of contract breach, or the cognition that the organisation has failed to fulfill its obligations (Zhao, Wayne, Glibkowski, \& Bravo, 2007).

$\mathrm{Ng}$ and Feldman (2009) presented theoretical arguments based on socioemotional selectivity theory (Carstensen, 2006) for a less intense effect of psychological contract breach on attitudinal and behavioral outcomes among older workers than among younger workers. According to $\mathrm{Ng}$ and Feldman (2009), when employees become older, their psychological contracts become more malleable, meaning that older workers develop higher tolerance for contract deviations (i.e. contract breaches). This is due to older workers' emotional maturation and increased altruism. However, in general previous studies have found mixed results concerning age-related differences in the psychological contract (Bal et al., 2008; Bellou, 2009). Bal and colleagues (2008) showed in their meta-analysis that older workers reacted less strongly to contract breaches in terms of trust and affective commitment but also found stronger effects among older workers on job satisfaction. A limitation of the meta-analysis of Bal et al. (2008), however, was that the measure of age was based on mean age in individual studies, which is a proxy for age and therefore excluded variance within studies, or the extent to which there were many younger or older workers in the sample. Therefore, it is important to ascertain the influence of age using primary data, which can show how age influences the relationships. Moreover, the current research was designed to assess whether contract breach causes change in attitudes and behaviors over time. To ascertain these relationships, it is therefore necessary to longitudinally investigate the effects of contract breach on change in attitudes and behaviors over time. Finally, previous research on age-related differences in reactions to psychological contract breach did not investigate behavioral outcomes, such as job performance.

Given this evidence of the impact of employee age on employee attitudes and behaviors (De Lange et al., 2010; Kanfer \& Ackerman, 2004; Ng \& Feldman, 2008), we expect age to play a significant role in how employees respond to psychological contract breach. In the current paper we aim to 
extend existing psychological contract literature by investigating how psychological contract breach (economic, socio-emotional, and developmental breach; see Bal et al., 2010) relates to changes in work outcomes across time, as well as by examining whether these relations are moderated by age. Hypotheses will be tested based on three theoretical notions from earlier research. Affective events theory (Weiss \& Cropanzano, 1996) is used to explain the relationships between psychological contract breach and work outcomes. Furthermore, socio-emotional selectivity theory (Carstensen, 2006) and the process model of emotion regulation (Gross, 1998, 2001) are used to explain the fact that older workers react less intensely to psychological contract breach than younger workers. In line with previous research, we expect age to moderate the effects of contract breach with outcomes, rather than to directly influence outcomes (Bal et al., 2008, 2010). The current paper contributes to previous research in the following ways. First, the present study investigates a process model of how psychological contract breach is related to change in work outcomes over time. By controlling for stability in the work outcomes, we not only show that contract breach and work outcomes are correlated with each other, but that contract breach is related to changes in job satisfaction and job performance over time. Moreover, we investigate a longitudinal process model, suggested by Zhao et al. (2007), with job satisfaction mediating the relationship between contract breach and job performance. The study also contributes to previous research (e.g. Bal et al., 2008) by expanding the range of work outcomes, through including job performance as outcome. Finally, we test for the influence of job content and organisational tenure as possible confounders of the effects of age on the hypothesised relations.

\section{The Psychological Contract}

To understand the employment relation between an employee and his or her organisation, Rousseau (1995) developed the concept of the psychological contract. The psychological contract is defined as the employee's beliefs regarding mutual obligations between the employee and the organisation (Conway \& Briner, 2005; Rousseau, 1995). Psychological contracts differ from legal contracts such that psychological contracts are subjective in nature and exist in the eye of the beholder (Suazo, Martínez, \& Sandoval, 2009). Thus, the psychological contract is a metaphor for understanding perceived written and unwritten obligations between an employee and the organisation (Guest, 2004). Employees form perceptions of employer obligations and the extent to which their employer honors or fulfills its obligations. When the employee perceives that the organisation does not fulfill its obligations, psychological contract breach takes place. Psychological contract breach accordingly is defined as "the employee's perceptions regarding 
the extent to which the organisation has failed to fulfill its promises or obligations" (Zhao et al., 2007, p. 649).

In line with previous studies on psychological contracts (e.g. Bal et al., 2010), we include three main types of contract breach: economic breach refers to breach of those employer obligations that embody short-term specific monetary inducements which are primarily materialistic in nature (Raja, Johns, \& Ntalianis, 2004). Socio-emotional breach concerns breach of obligations of long-term exchanges that maintain the employee-employer relationship and are less specific in nature than breach of economic obligations (e.g. participation in decision making and interesting work; Zhao et al., 2007). Finally, developmental breach consists of employee training and developmental opportunities (Maurer, Weiss, \& Barbeite, 2003).

\section{An Affective Events Theory Perspective on the Effects of Psychological Contract Breach on Work Outcomes}

Previous studies on the effects of psychological contracts have shown that perceptions of contract breach are profoundly related to work outcomes. Researchers have used affective events theory (AET) to explain the process of how psychological contract breach influences work outcomes (Weiss \& Cropanzano, 1996; Zhao et al., 2007). According to AET, events at the workplace often evoke emotional reactions among people (Weiss \& Cropanzano, 1996). It is through these affective experiences that employees' attitudes and behaviors are influenced. Thus, a negative event at the workplace colors the cognitive evaluations of one's job, in such a way that experience of negative events will cause a more negative view of the job and consequently lower motivation to put effort into the job (Thoresen, Kaplan, Barsky, Warren, \& de Chermont, 2003). Zhao and colleagues (2007) argued that psychological contract breaches, in particular, are perceived as negative emotional events. Contract breach refers to work events where an employee perceives that organisational obligations are not kept, and thus is inherently related to affective reactions, which in turn contribute to the establishment of job satisfaction and job performance.

In this study, we focus on the effects on two core work outcome variables that have been identified as crucial in upholding employee motivation and effectiveness: job satisfaction and job performance (Harrison, Newman, \& Roth, 2006). Job satisfaction and job performance are two of the most central constructs in organisational psychology and are crucially important for employees in their motivation and effectiveness at work (Harrison et al., 2006). According to AET, negative events (e.g. contract breaches) influence an employee's state of mind, consequently leading to work attitudes (i.e. job satisfaction) and work behaviors (i.e. job performance; Weiss \& Cropanzano, 1996). Hence, AET proposes a mediated effect of job satisfaction in the 
relation between contract breach and job performance (Zhao et al., 2007). In sum, we expect that psychological contract breach is negatively related to changes in job performance over time, and this relationship is mediated by job satisfaction. Hypothesis 1 is:

H1: The negative relation between psychological contract breach (economic, socio-emotional, and developmental) and job performance over time is mediated by job satisfaction.

\section{Age-Related Differences in the Relations between Contract Breach and Work Outcomes}

Furthermore, based on socio-emotional selectivity theory (Carstensen, 2006) and the model of emotion regulation (Gross, 2001), we expect age to moderate the relations between contract breach and work outcomes. Socioemotional selectivity theory (Carstensen, 2006; Carstensen \& Mikels, 2005) and the model of emotion regulation (Gross, 1998, 2001; Gross, Carstensen, Pasupathi, Tsai, Skorpen, \& Hsu, 1997; John \& Gross, 2004) have been used extensively in understanding how older people differ from younger people in motivation and behavior, as well as in explaining the impact of age on work behaviors (see e.g. Davis, Kraus, \& Copabianco, 2009; Kooij, De Lange, Jansen, Kanfer, \& Dikkers, 2011; Ng \& Feldman, 2009).

Socio-emotional selectivity theory states that in young adulthood time is perceived as expansive (Carstensen, Isaacowitz, \& Charles, 1999). Young people prepare for a long and unknown future and therefore primarily focus on growth and knowledge-related goals. For older people, however, the experience of approaching the end of life causes a shift towards presentrelated emotional goals over knowledge goals, and a focus on emotional well-being. Older people increasingly focus on the present, and in particular on maintaining positive feelings and avoidance of negative feelings (Carstensen, Fung, \& Charles, 2003; Carstensen \& Mikels, 2005). Although older people may be sensitive to emotional situations, they are more focused on maintaining positive feelings (Carstensen \& Mikels, 2005; Kunzmann \& Richter, 2009). Therefore, even though both younger workers and older workers experience contract breach as a negative event, older workers are expected to be more focused on maintaining a positive relationship with their organisation when their psychological contract has been broken. Consequently, older workers' satisfaction and performance are influenced less strongly by negative events than is the case for younger workers, whose needs for growth and learning are impeded by contract breaches.

The process model of emotion regulation provides further evidence for why older workers will react differently from younger workers to contract breaches (Diamond \& Aspinwall, 2003; Gross, 1998, 2001; Gross et al., 1997; 
John \& Gross, 2004). With increasing maturity, people learn to cope with their emotions, and are better at interpreting, managing, and deriving meaning from conflicting emotions (Diamond \& Aspinwall, 2003; Heckhausen, Wrosch, \& Schulz, 2010). Hence, older people are better at regulating their emotions after negative events than younger people (Carstensen, 1995; Carstensen et al., 2003). Moreover, when older people experience negative emotions, they are quicker at returning to positive moods than younger people (Carstensen, Pasupathi, Mayr, \& Nesselroade, 2000; John \& Gross, 2004; Lawton, Kleban, Rajagopal, \& Dean, 1992). Research has shown that older people may experience similar emotions to younger people immediately after experiencing a negative event, but their attitudinal and behavioral reactions are less intense than those of younger people (Kunzmann, Kupperbusch, \& Levenson, 2005; Kunzmann \& Richter, 2009). Thus, in general younger workers react more intensely to negative events than older workers.

There are some empirical investigations of this notion in the work setting. The aforementioned meta-analysis of Bal and colleagues (2008) showed some age-related differences in reactions to psychological contract breach. Moreover, Cohen (1991) found that the relation between organisational commitment and turnover was stronger for younger workers than for older workers. Finally, other studies have found stronger reactions among younger workers as well (e.g. Wagner \& Rush, 2000). Based on these findings, we argue that the relations of contract breach with changes in work outcomes over time weaken with age. This is because older workers are more focused on positive aspects of their relationship with their organisation (socio-emotional selectivity), and because they are better at regulating their emotions after negative events (such as contract breach) and are quicker at returning to positive moods after contract breach (enhanced emotion regulation skills). The second hypothesis is:

H2: Age moderates the relations between psychological contract breach and changes in (a) job satisfaction and (b) job performance over time, such that the relations are stronger for younger workers than for older workers.

\section{METHOD}

\section{Sample and Procedure}

This study was conducted in a Dutch division of a multinational risk management organisation. In June 2006 (T1), 1,298 employees were invited to participate in the study at the first measurement. In June 2007 (T2), all respondents at $\mathrm{T} 1$ were emailed and asked to participate in a follow-up study. Because the participating organisation held its yearly performance appraisals with the employees in May, the questionnaires were distributed in June, so 
that employees had received evaluations by their supervisors and were already prompted to think about their performance in the previous year. Therefore, it was deemed appropriate to assess whether employees experienced contract breach at $\mathrm{T} 1$, and whether their performance had changed a year later (T2). The review study of De Lange, Taris, Kompier, Houtman, and Bongers (2003) also indicated that the effects of job demands on wellbeing could best be demonstrated with studies using a time lag of one year. By means of online survey software employees were asked to fill out the questionnaire, resulting in a total response of $N=727$ (response rate $56 \%$ ) at T1. Of the 727 participants at T1, 240 responded to the second questionnaire (response of 33\%; overall response rate 18\%). Analyses showed that the final sample did not differ significantly from the company's total employee population in terms of age, gender, tenure, contract, or educational level. Further analyses showed that the sample at $\mathrm{T} 2$ did not differ significantly on any demographic variable from the sample at T1. Among the respondents at T1, 9 per cent had left the company at $\mathrm{T} 2$.

Of the 240 participants, 40 per cent were female, at $\mathrm{T} 1$ the average age was 42 years $(S D=9.27$; range 19-63 years), the average organisational tenure was 11 years $(S D=10.39)$, and average job tenure was 6 years $(S D=5.37)$. Of the employees, 96 per cent had a permanent contract, 76 per cent worked full-time, and 17 per cent of the respondents had a university degree. Age was measured as a continuous variable at T1. Regarding age, 12.5 per cent of the respondents were 30 years or younger, 35 per cent were between 31 and 40 years old, 31.3 per cent were between 41 and 50 years, 20.8 per cent were between 51 and 60 years old, and 0.4 per cent were 61 years or older.

\section{Measures}

Psychological Contract Breach. We measured contract breach using the three economic, socio-emotional, and developmental breach scales at T1 with an adapted measure of Coyle-Shapiro and Conway (2005; see Bal et al., 2010). Respondents indicated the extent to which they felt their employer had fulfilled a list of obligations (Coyle-Shapiro \& Conway, 2005; De Vos, Buyens, \& Schalk, 2003). We checked whether psychological contract obligations as measured in the current study were indeed part of perceived obligations by the participating organisation towards their employees, through interviews with HR managers in the organisation prior to the study. Scores were reversed to indicate psychological contract breach (see Zhao et al., 2007). The items were measured on a 5-point Likert scale ("not at all" to "to a very great extent"). Economic breach $(\alpha=.85)$ was measured with five items, an example being "fair pay for the responsibilities of the job". Socio-emotional breach $(\alpha=.77)$ was measured with four items. An example item is "opportunities to be involved in decisions that affect me". Develop- 
mental breach $(\alpha=.82)$ was measured with three items, an example being "career support and mentoring". The three contract breach scales were used as indicators of the contract breach scale, which obtained a reliability of .87 .

Work-Related Outcomes. Job satisfaction and job performance were both measured both at T1 and T2. Job satisfaction was measured with the four-item job satisfaction scale from the Copenhagen Psychosocial Questionnaire (COPSOQ; Kristensen, Bjorner, Christensen, \& Borg, 2004; Kristensen, Hannerz, Høgh, \& Borg, 2005). The scale measured the extent to which respondents felt they were satisfied with their work prospects, physical work conditions, the way their abilities are used, and their job as a whole. Reliability was .71 at T1 and .76 at T2. Self-rated job performance was measured with three items from Williams and Anderson (1991). Whereas self-rated job performance may be a less objective indicator of performance than measures such as sales rates (Williams \& Anderson, 1991), the measure of job performance that is used in the current study indicates an assessment by the employee about their performance on the job (see e.g. Bal et al., 2010; De Vos et al., 2003). Subjective performance measures are valid for the current study. First, objective and subjective measures of performance are positively correlated and are similarly predicted by independent variables (Bommer, Johnson, Rich, Podsakoff, \& MacKenzie, 1995; Wall, Michie, Patterson, Wood, Sheehan, Clegg, \& West, 2004). Moreover, subordinates' perceptions of their own performance add to other ratings of performance (e.g. objective performance and supervisor rated performance) since they contribute in a unique way to the overall concept of performance (Conway \& Huffcutt, 1997). Moreover, Sturman, Cheramie, and Cashen (2005), in their meta-analysis, showed that subjective ratings of performance are more reliable over time than objective ratings. Since our study focused on change of job performance over time, we deemed it appropriate to have subjective ratings of performance. Respondents rated the extent to which three items were representative for their behavior at work on a 6-point scale ranging from $1=$ "not at all" to $6=$ "to a very great extent". The three items were selected based on the items with the highest factor loadings in the Williams and Anderson (1991) study. The items were: "Adequately complete assigned duties", "Fulfill responsibilities specified in job description", and "Perform tasks that are expected of you". Reliability at T1 was .83 and at T2 .84.

\section{Analysis}

To investigate the construct validity of the psychological contract breach measures and the work outcomes, measurement models including all items were tested by means of confirmatory factor analyses (CFA with Lisrel 8.72; Jöreskog \& Sörbom, 2005). To evaluate models, established goodness-of-fit 
indices were used (Hu \& Bentler, 1999). For the Root Mean Square Error of Approximation, a value of .05 or below is indicated as good fit, and below .08 as acceptable (MacCallum, Browne, \& Sugawara, 1996). Further, the Standardised Root Mean Square Residual (SRMR) should be lower than .05. The Non-Normed Fit Index (NNFI), Comparative Fit Index (CFI), and Incremental Fit Index (IFI) should all be above .90. First, a baseline model was tested with seven factors (the three contract breach types, job satisfaction at $\mathrm{T} 1$ and $\mathrm{T} 2$, and job performance at T1 and T2). Subsequently, we tested whether the model improved when a second-order factor was added for the three contract breach types. The baseline model was further tested against a range of models with fewer factors, and a model including an unmeasured latent factor in order to control for common method bias. The proposed seven-factor model reached acceptable fit $\left(\chi^{2}=633.28, d f=251 ; p<.001\right.$; RMSEA $=.07$; SRMR $=.06$; CFI $=.96$ ). All items loaded significantly on their latent factor with factor loadings well above .45. The Appendix presents various models that were tested. Moreover, the seven-factor model fit significantly better than the other models. The model with the second-order factor for contract breach did not reach a significantly improved fit; however, the paths from the three types to contract breach were significant and ranged from .61 to .72 . Hence, it was deemed appropriate to construct a latent variable for contract breach consisting of the three contract breach types.

Hypotheses were tested with moderated structural equation modeling using Lisrel 8.72 (MSEM; Jöreskog \& Sörbom, 2005). All independent variables were mean-centered before interactions were calculated. One latent factor contract breach was constructed with the three contract breach scales as indicators. For job satisfaction and job performance, scale items served as indicators of the latent variables. We built different models to test the mediating role of job satisfaction in the relation between contract breach and job performance T2 (according to recommendations by Baron \& Kenny, 1986). First, we tested a model $M_{1}$ to investigate whether contract breach was related to change in job performance. Paths were included from contract breach and job performance T1 to job performance T2. Subsequently, we tested a model $\mathrm{M}_{2}$ to test whether contract breach was related to job satisfaction T2, with paths from contract breach and job satisfaction T1 to job satisfaction T2. Moreover, we tested three other models to investigate whether a partial mediation (paths from contract breach to job satisfaction $\mathrm{T} 2$ and job performance $\mathrm{T} 2$, from job satisfaction $\mathrm{T} 2$ to job performance $\mathrm{T} 2$, and stability of job satisfaction and performance over time), a full mediation (partial mediation model excluding direct path from contract breach to job performance T2) or a direct effects model produced the best fit (only paths from contract breach to job satisfaction T2 and job performance T2, and stability paths; see Zhao et al., 2007). To conduct the moderator analyses, the procedure of Mathieu, Tannenbaum, and Salas (1992; see also Cortina, 
Chen, \& Dunlap, 2001) was followed. The results are shown in Model $\mathbf{M}_{6}$ (shown in Figure 1). Finally, Model $\mathbf{M}_{7}$ was constructed to test for reversed causation of job satisfaction $\mathrm{T} 1$ and job performance $\mathrm{T} 1$ as predictors of contract breach T2 (which was not included in the other analyses).

For all the models, work outcomes at $\mathrm{T} 1$ were included to calculate changes in the outcomes over the year as a consequence of the independent variables. Next, the interaction model was tested including interactions between contract breach and age in relation to job satisfaction T2 and job performance T2. The latent variable age had one indicator. The paths from this latent factor to the indicator were fixed with the square root of the scale reliability, which was estimated at a conservative .90 , whereas the error variance of the indicator was set equal to the product of their variances and one minus the reliability. A similar procedure was followed for the latent interaction term (see Cortina et al., 2001, for an extensive description of the procedure). Moreover, the correlation between age and the interaction term was set to zero, as well as the correlation between contract breach and the interaction term. In line with recommendations of Cortina et al. (2001), we set these correlations to zero because we expected little relationship between the interaction term and the main effect variables, which results in fewer model identification problems (Cortina et al., 2001, p. 329). For the endogenous variables, we used total disaggregation models with the separate items as indicators of the latent variable (Bagozzi \& Edwards, 1998). Job satisfaction T1 was treated as predictor of job satisfaction T2, and hence the other predictors refer to change in job satisfaction over time. The same procedure was conducted for job performance. Significant interactions were plotted using simple slope analysis with slopes one standard deviation below and above the mean of the moderator, in line with recommendations of Aiken and West (1991). Table 1 presents the means and standard deviations, alpha coefficients, and correlations among the variables. Age was not significantly related to contract breach, indicating that older workers did not differ from younger workers in their perceptions of contract breach.

A possible confounder in the current study is that older workers might have jobs that are different from those of younger workers (e.g. more demanding or resourceful jobs; Ng \& Feldman, 2008), and therefore react differently from younger workers to psychological contract breach. We therefore included scales from the COPSOQ job characteristics survey of Kristensen and colleagues (2004) in the survey at time 1. We investigated job demands, autonomy, opportunities to use skills in the job, social support from the supervisor, and the availability of learning opportunities in the job (all scales were reliable with Cronbach's alphas above .75). It was found that age was not significantly correlated to any of these job characteristics (correlations ranging from $r=-.03$ to $r=.10$ ), suggesting that older workers' perceptions of their jobs did not differ from those of younger workers. In 


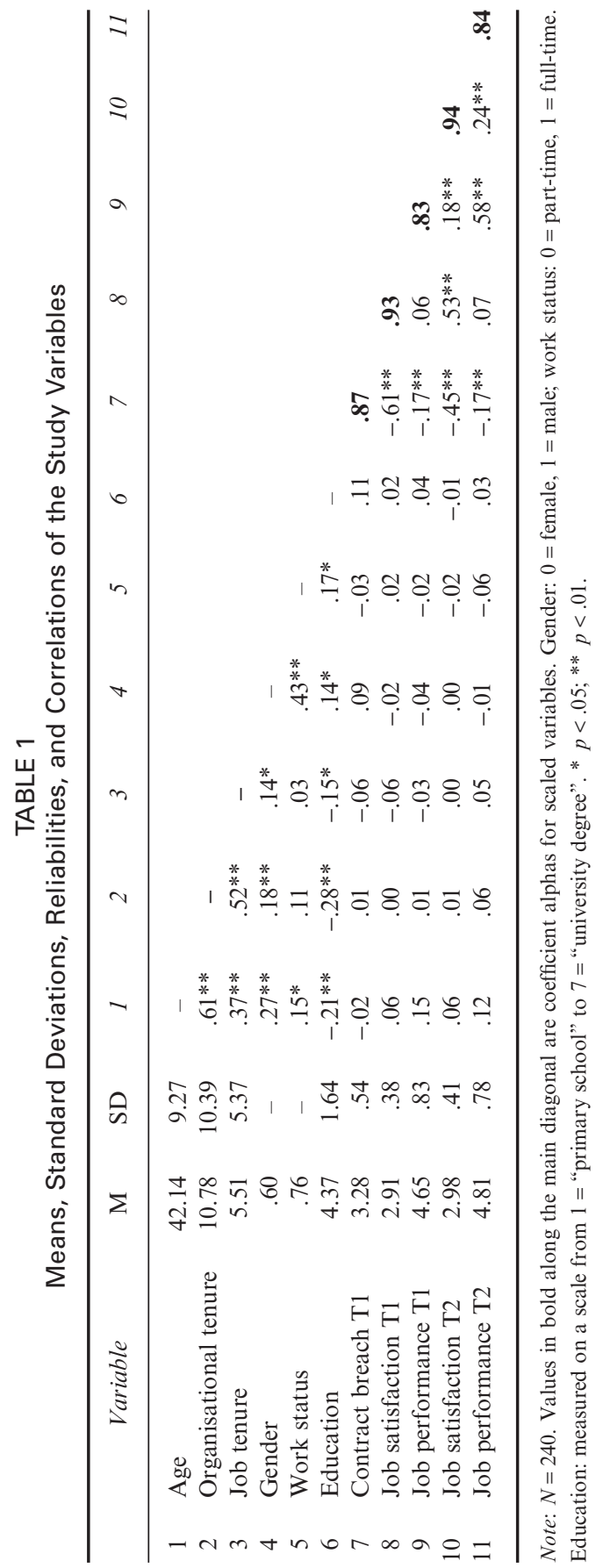

(C) 2012 The Authors. Applied Psychology: An International Review (C) 2012 International Association of Applied Psychology. 
addition, no significant curvilinear relations were found between age and the job characteristics. Consequently, the job characteristics were excluded from further analysis.

\section{RESULTS}

Hypothesis 1 predicted that the relation between psychological contract breach and job performance was mediated by job satisfaction. Table 2 shows the results of the various structural equation models that were tested and Table 3 shows the coefficients of the paths in the various models. The partial mediation model obtained the best fit, and a full mediation model and a direct effects model did not obtain a significantly better fit. Hence, job satisfaction only partially mediated the relationships between contract breach and job performance. Contract breach was negatively related to job performance T2 $(b=-.18, p<.001)$, thereby supporting the first condition for mediation. Contract breach was also significantly related to job satisfaction T2 $(b=-.40, p<.001)$, thereby supporting the second condition for mediation. We further tested the third condition for mediation through fitting a partial mediation model including a path from job satisfaction $\mathrm{T} 2$ to job performance T2, which was significant $(b=.25, p<.01)$. However, the full mediation model did not reach a significantly better fit than the partial mediation model. Moreover, the relation between contract breach and job performance T2 was still significant when job satisfaction T2 was accounted for $(b=-.16, p<.01)$. We also tested an alternative model $\mathrm{M}_{7}$, in which reversed causation was tested with job satisfaction $\mathrm{T} 1$ and job performance $\mathrm{T} 1$ predicted contract breach T2. After controlling for the stability in contract breach over time (indicated by a path from contract breach $\mathrm{T} 1$ to contract breach T2; $b=.81, p<.001)$, neither job satisfaction $\mathrm{T} 1(b=-.14$, $n s)$ nor job performance T1 $(b=-.06, n s)$ was significantly related to contract breach T2. Therefore, we found no evidence for reversed causation. In all, Hypothesis 1 is partly supported: job satisfaction partially mediated the relationship between contract breach and job performance.

Hypothesis 2 predicted stronger reactions among younger workers to psychological contract breach than among older workers. Hypothesis 2 was tested through including main effects of age and the interaction between age and contract breach $\mathrm{T} 1$ in the model, with paths to job satisfaction T2 and job performance T2. Table 2 shows the fit statistics of the Model $\mathbf{M}_{6}$ and Figure 1 shows the standardised coefficients of Model $\mathrm{M}_{6}$, the partial mediation model including the interactions.

The analyses show strong support for the impact of age on the relations between contract breach and work outcomes. Age interacted significantly with contract breach in relation to job satisfaction T2 $(b=.16, p<.05)$. The slope was negative for younger workers (1 standard deviation below the 


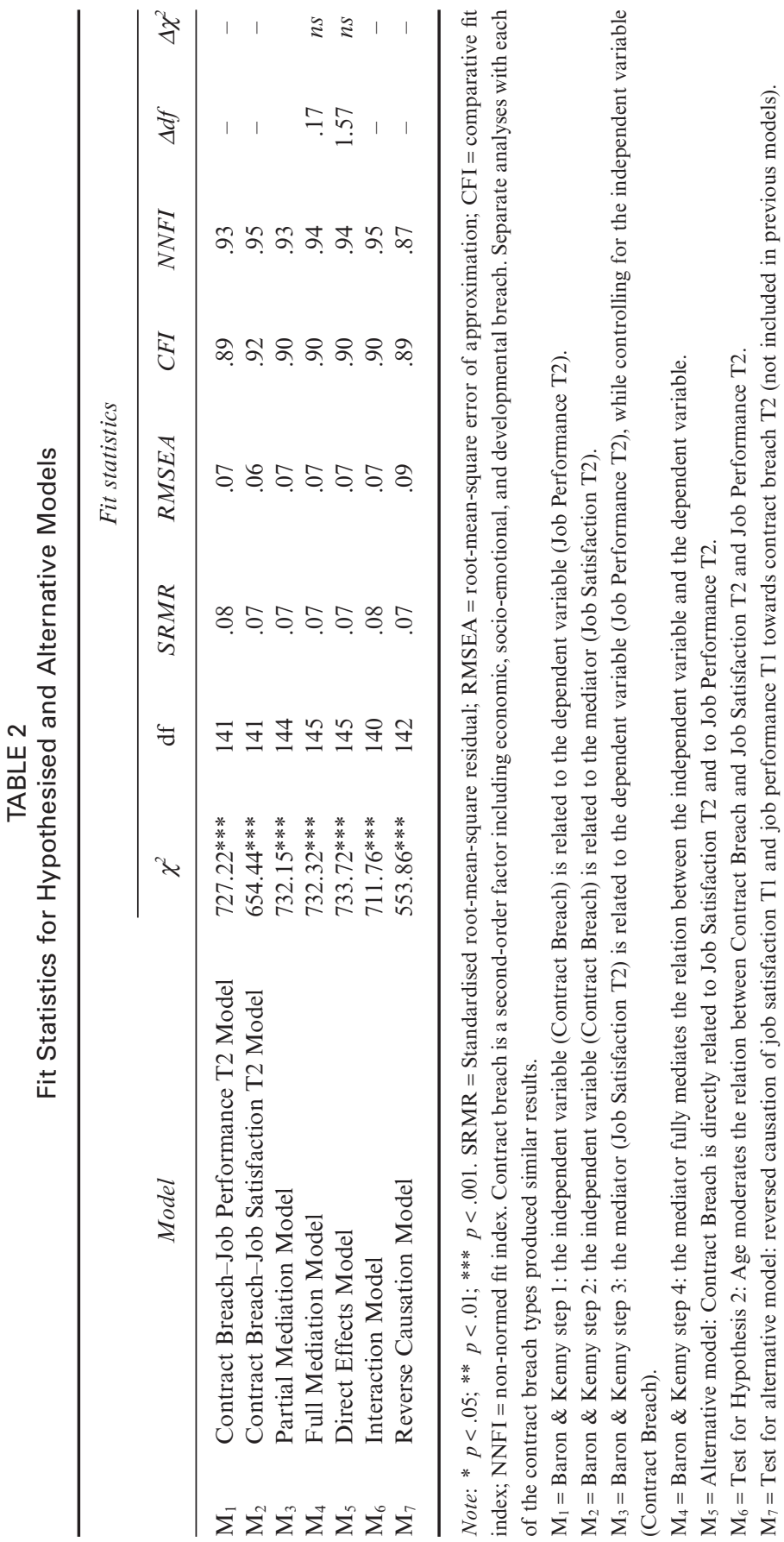

(C) 2012 The Authors. Applied Psychology: An International Review (C) 2012 International Association of Applied Psychology. 


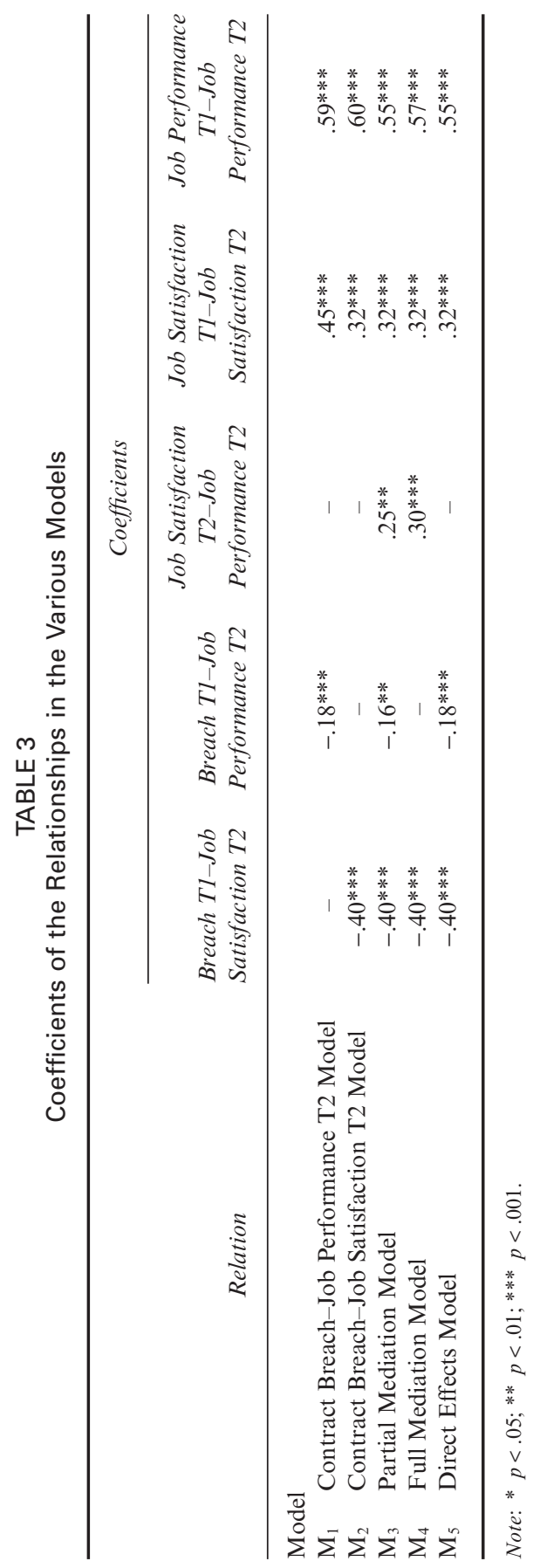

(C) 2012 The Authors. Applied Psychology: An International Review (C) 2012 International Association of Applied Psychology. 


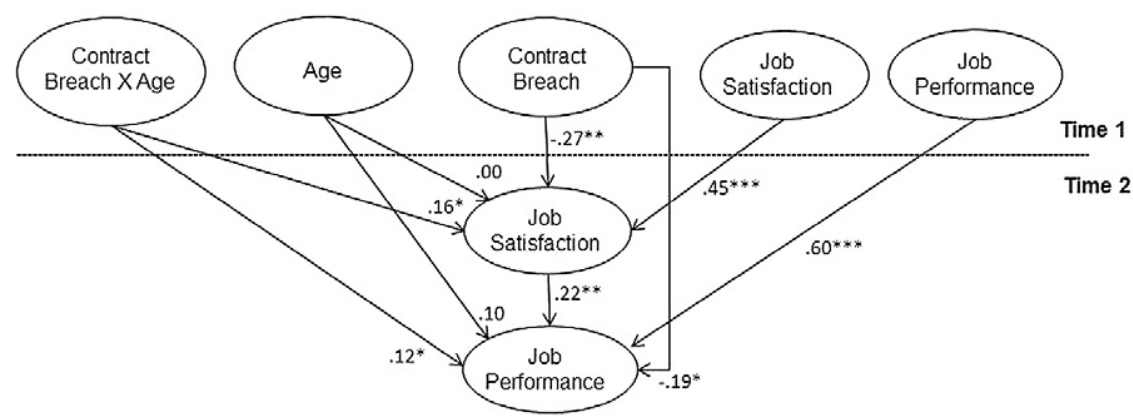

FIGURE 1. Results of the structural model for the relations of contract breach with changes in job satisfaction and job performance over time, and the interaction between age and contract breach in relation to changes in job satisfaction and job performance over time. Lines from the latent variables to their indicators are not shown for the clarity of the figures.

Note: ${ }^{*} p<.05 ;{ }^{* *} p<.01 ;{ }^{* *} p<.001$.

mean: 32.9 years: $b=-.37, p<.001$ ), while the relation was less strong for older workers (1 SD above the mean: 51.4 years: $b=-.13, p<.05)$. Age also interacted significantly with contract breach in relation to job performance $(b=.12, p<.05)$. Figure 2 shows the interaction pattern. The slope was negative for younger workers $(b=-.20, p<.01)$ while the relation was not significant for older workers $(b=-.04, n s)$. In sum, the relations between contract breach and changes in job satisfaction and job performance over time were stronger for younger workers than for older workers, thereby providing support for Hypothesis 2.

\section{Supplementary Analyses}

To estimate the validity of our results, we conducted a robustness test, by creating 10 random samples (each consisting of about $50 \%$ of the total sample) from the total dataset of 240 employees. Subsequently, hypotheses were tested for each of the 10 samples, producing 60 estimates of the interactions between age and the three contract breach types in relation to the outcomes (job satisfaction T2 and job performance T2). On average, power to detect significant interactions decreased from .47 in the original analyses (including 240 respondents) to .31 for the random samples. Coefficients ranged from -.04 to $.29, p<.001$, and delta $R$-squared ranged from .00 to .12 . However, even though power to detect significant interactions substantially decreased due to the smaller sample sizes, 58 per cent of the interactions were 


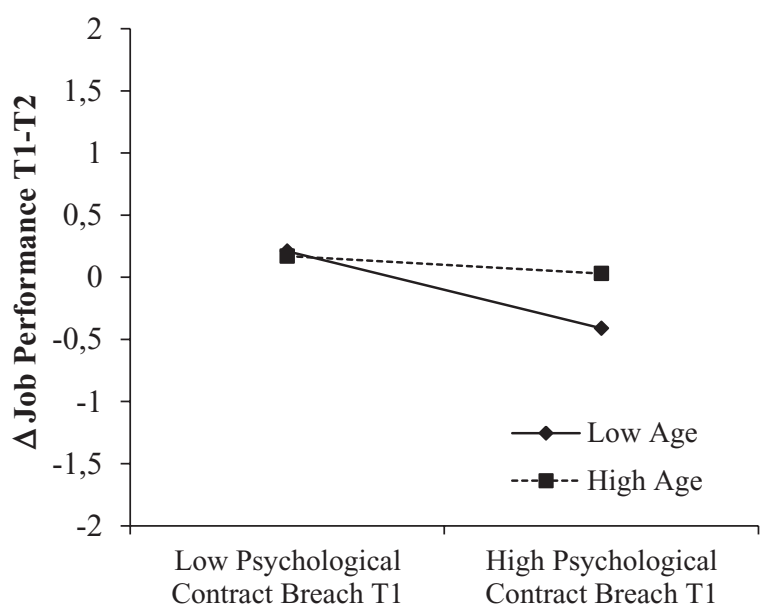

FIGURE 2. Interaction effect of contract breach and age in relation to change in job performance over time.

still significant, and in the same direction as the total interaction effects. In sum, we believe that our results can be largely replicated through random sampling.

An alternative explanation of the results could be that changes in workers' reactions towards psychological contract breaches are not the result of aging processes but occur because of longer tenure with the organisation (Rousseau \& Parks, 1993; Wright \& Bonett, 2002). Therefore, hypotheses were tested with organisational tenure as moderator in the relations of psychological contract breach with job satisfaction and performance. Neither the moderating effect of organisational tenure on the relations of contract breach with job satisfaction $(b=.00)$ nor with job performance was significant $(b=.05)$. Therefore, it can be concluded that less intense reactions of older workers to contract breaches are due to greater age rather than to longer tenure with their organisation.

\section{DISCUSSION}

The present study shows that job satisfaction partially mediates the longitudinal relationship between psychological contract breach and changes in job performance (Zhao et al., 2007). Moreover, the study shows that age has an important impact on how psychological contract breach is related to changes in work outcomes over time. Through perceptions of contract breach, in particular, people adapt their attitudes towards the organisation and conse- 
quently the effort they put into the job (Zhao et al., 2007). However, the results showed that these relations are contingent on employee age; in general, younger workers react more intensely to contract breach, regardless of the type of breach (economic, socio-emotional, or developmental). The interaction patterns between age and contract breach revealed that in cases of serious contract breach, in particular, job satisfaction and job performance of younger workers became lower than those of older workers. A possible explanation is that older workers are able to buffer the negative effects of contract breach by regulating their emotions in a constructive way (Davis et al., 2009; Ng \& Feldman, 2009). Even though contract breaches may be strongly related to changes in job satisfaction and job performance, older workers' job satisfaction and job performance are less influenced by contract breaches than younger workers'.

Perceptions of psychological contract breach have less impact on work outcomes among older workers than among younger workers. Alternative explanations of the current results were ruled out by showing that organisational tenure did not moderate the relations between contract breach and work outcomes, and that job characteristics were not significantly different among younger and older workers, and therefore older employees do not react differently to psychological contract breaches because they have more demanding or resourceful jobs than younger workers.

The findings of the current study are in line with notions of socioemotional selectivity theory (Carstensen, 2006), which suggests that since older people focus increasingly on positive aspects in their work and avoid negative feelings, their satisfaction and performance are harmed less severely when contract breach occurs than is the case for younger workers. Another explanation for the current results can be found in emotion regulation (Gross, 2001). Accordingly, with increasing maturity people learn to cope with their emotions and are better at interpreting, managing, and deriving meaning from conflicting emotions (Diamond \& Aspinwall, 2003). For instance, facing interpersonal tensions, older people are more likely to report fewer negative emotions than younger people (Birditt, Fingerman, \& Almeida, 2005), and older people are better at regulating their emotions after negative events than younger people and are quicker at returning to positive moods (Carstensen, 1995; Carstensen et al., 2003; John \& Gross, 2004). Therefore, consequences of emotional reactions tend to be more intense for younger people than for older people (Gross et al., 1997). This also applies to reactions to psychological contract breaches, where younger workers reacted more intensely in terms of decreased job satisfaction and job performance.

The findings of the current study are partly in line with the work of Zhao and colleagues (2007), who explained the relations of psychological contract breach with work outcomes using an affective events framework (Weiss \& Cropanzano, 1996). Psychological contract evaluations are triggered by

(C) 2012 The Authors. Applied Psychology: An International Review (C) 2012 International Association of Applied Psychology. 
events that take place and which are emotionally meaningful (Zhao et al., 2007). Emotions are informational and motivational (Izard, 2009). Thus, psychological contracts are inherently affective in nature (Morrison \& Robinson, 1997). Therefore, taking an emotion regulation perspective on the effects of psychological contracts on job attitudes and work behaviors explains differences between younger and older workers in how they respond to contract fulfillments and breaches. Moreover, we have investigated three types of contact breach, which, due to their empirical overlap, we combined in one second-order breach factor in order to obtain a more parsimonious model. Previous research (e.g. Morrison \& Robinson, 1997) has used contract breach as a single construct, and it may consist of assessments regarding multiple components in the psychological contract; these tend to correlate highly. Hence, the extent to which employees perceive their psychological contract to be broken consists of breach of multiple components rather than a specific domain. For future research on contract breach, how these components interact and complement each other should be further investigated.

The findings concerning job satisfaction were in contrast to those of Bal et al. (2008), who found in their meta-analysis that correlations of contract breach with job satisfaction were stronger for older workers than for younger workers. Bal et al. (2008) explained their finding in that job satisfaction is not primarily aimed at the organisation, such as trust in the organisation and commitment. However, these differences can be explained in that the current study used age of employees as a moderator, rather than a proxy of age by using mean age in the meta-analysis. Moreover, another explanation is that the current study was based in the Netherlands, and that older workers react less intensely because they have fewer job alternatives (Kooij et al., 2008, 2011). In other words, because they know that they could not easily find a new job, they maintain job satisfaction, even though their contract has been broken.

\section{Limitations of the Present Study}

The study also has some limitations. First, we could not distinguish between age and cohort effects. Hence, possible differences in reactions to psychological contracts might be attributed to generational differences as well as to aging processes (Schaie, 1986; Smola \& Sutton, 2002). It might be that younger workers react more strongly to contract breaches because they were raised in a different age from the older workers, who were primarily baby boomers. Therefore, future research should also investigate generational differences in psychological contracts. Second, all data were collected through self-reports. This could lead to common method bias (Podsakoff, MacKenzie, Lee, \& Podsakoff, 2003). However, through our longitudinal 
design we have tried to minimise common method bias. Furthermore, the explained variance of the interaction terms was between 1 and 2 per cent. Although it may seem that the explained variance of the interactions was not high, previous research has shown that in field studies it might be harder to detect interaction effects (McClelland \& Judd, 1993). Therefore, interaction effects of limited sizes are meaningful in understanding the role of age in organisational research. Finally, healthy worker effects could influence the results (Zapf, Dormann, \& Frese, 1996). There is a selection effect of healthy people staying in the workforce and unhealthy people quitting the workforce. However, since older workers in the study are the healthy and motivated survivors, this study may be a study of survival behavior in organisations (Noonan, 2005). By reacting less intensely than younger workers to contract breach, older workers may survive within the organisation. Finally, a limitation was that we did not include emotional reactions as mediators in the relationships between contract breach and outcomes. Therefore, it could be that older workers react less intensely because they have fewer job opportunities. It is therefore imperative for future research to include the full model as proposed by Zhao et al. (2007), which includes emotions as well as work outcomes.

\section{Suggestions for Future Research}

This study focused on the moderating effects of age on self-reported work outcomes; future research should also investigate objective measures of work behaviors, such as objective performance, absenteeism, and turnover. In line with the findings of Zhao et al. (2007), psychological contract breach is related to several types of work behaviors, and it may be that age also moderates the relations of contract breach with objective outcomes.

Further, due to shortages in the labor market and recent changes in retirement ages, more people will be working after the age of 65 . However, older workers (age $>50$ ) are underrepresented in psychological contract research to date. We therefore need additional research that includes employees with a wider age range in order to investigate more specifically how older workers perceive their psychological contracts. It is also important to investigate how psychological contracts develop when people continue working after retirement, since it is likely that more and more workers will be active at an older age (Bal et al., 2010; Peterson \& Spiker, 2005).

Finally, age is a proxy of several age-related changes that people experience, and refers to biological, psychological, social, and societal changes (De Lange, Taris, Jansen, Smulder, Houtman, \& Kompier, 2006). For instance, age is linked to time spent within the organisation or job (Wright \& Bonett, 2002), family status (Roehling, Roehling, \& Moen, 2001), and to future time perspectives (Lang \& Carstensen, 2002). Thus, the influence of age could be

(C) 2012 The Authors. Applied Psychology: An International Review (C) 2012 International Association of Applied Psychology. 
a proxy effect of other relevant age-related factors. Future research should study in depth how age-related factors, such as tenure and family status, are related to the psychological contract.

\section{Practical Implications}

The results of the current study also have important implications for organisational practice. The study has shown that for younger workers it is important to fulfill the psychological contract to maintain and enhance positive attitudes towards the job. If they perceive that the employer does not fulfill its obligations towards them, their satisfaction will be lower and they will feel less obligated towards the organisation to perform well. For older workers, however, the impact of contract breaches is less visible. Older workers are more focused on positive emotions and tend to avoid negative emotions impacting their work, and they are also better at regulating emotions after negative events, such as contract breach. They are generally more benevolent employees (Ng \& Feldman, 2008; Wagner \& Rush, 2000), and their attitudes towards the job and their performance are less influenced by contract breach (Bal et al., 2008).

Therefore, organisations can benefit more from their older workers by offering them more complex tasks and projects, because older workers are better at regulating their negative emotions and dealing with complex issues (Bal et al., 2010). Older workers' decreased emotional responsiveness towards negative events at the workplace makes them more emotionally stable employees, and therefore attractive in work settings where regulation of emotions plays an important role, such as police work and teaching.

\section{Conclusion}

This study showed that age plays an important role in how psychological contract breach affects job attitudes and behaviors. We integrated theoretical perspectives from affective events theory (Weiss \& Cropanzano, 1996), the model of emotion regulation (Gross, 1998), and socio-emotional selectivity theory (Carstensen, 2006) with psychological contract research and found that when people grow older, reactions towards psychological contract breach decrease in strength. Older workers have less intense reactions to psychological contract breach than younger workers, perhaps indicating better emotion regulation of older workers after psychological contract breaches.

\section{REFERENCES}

Aiken, L.S., \& West, S.G. (1991). Multiple regression: Testing and interpreting interactions. San Francisco, CA: Sage Publications. 
Bagozzi, R.P., \& Edwards, J.R. (1998). A general approach for representing constructs in organizational research. Organizational Research Methods, 1, 45-87.

Bal, P.M., De Lange, A.H., Jansen, P.G.W., \& Van der Velde, M.E.G. (2008). Psychological contract breach and job attitudes: A meta-analysis of age as a moderator. Journal of Vocational Behavior, 72, 143-158.

Bal, P.M., Jansen, P.G.W., Van der Velde, M.E.G., De Lange, A.H., \& Rousseau, D.M. (2010). The role of future time perspective in psychological contracts: A study among older workers. Journal of Vocational Behavior, 76, 474- 486.

Baron, R.M., \& Kenny, D.A. (1986). The moderator-mediator variable distinction in social psychological research: Conceptual, strategic, and statistical considerations. Journal of Personality and Social Psychology, 51, 1173-1182.

Bellou, V. (2009). Profiling the desirable psychological contract for different groups of employees: Evidence from Greece. International Journal of Human Resource Management, 20, 810-830.

Birditt, K.S., Fingerman, K.L., \& Almeida, D.M. (2005). Age differences in exposure and reactions to interpersonal tensions: A daily diary study. Psychology and Aging, 20, 330-340.

Bommer, W.H., Johnson, J.L., Rich, G.A., Podsakoff, P.M., \& MacKenzie, S.B. (1995). On the interchangeability of objective and subjective measures of employee performance: A meta-analysis. Personnel Psychology, 48, 587-605.

Carstensen, L.L. (1995). Evidence for a life-span theory of socioemotional selectivity. Current Directions in Psychological Science, 4, 151-156.

Carstensen, L.L. (2006). The influence of a sense of time on human development. Science, 312, 1913-1915.

Carstensen, L.L., Fung, H.H., \& Charles, S.T. (2003). Socioemotional selectivity theory and the regulation of emotion in the second half of life. Motivation and Emotion, 27, 103-123.

Carstensen, L.L., Isaacowitz, D.M., \& Charles, S.T. (1999). Taking time seriously: A theory of socioemotional selectivity. American Psychologist, 54, 165-181.

Carstensen, L.L., \& Mikels, J.A. (2005). At the intersection of emotion and cognition: Aging and the positivity effect. Current Directions in Psychological Science, 14, 117-121.

Carstensen, L.L., Pasupathi, M., Mayr, U., \& Nesselroade, J.R. (2000). Emotional experience in everyday life across the adult life span. Journal of Personality and Social Psychology, 79, 644-655.

Cohen, A.A. (1991). Career stage as moderator of the relationships between organizational commitment and its outcomes: A meta-analysis. Journal of Occupational Psychology, 64, 253-268.

Conway, N., \& Briner, R.B. (2005). Understanding psychological contracts at work: A critical evaluation of theory and research. Oxford: Oxford University Press.

Conway, J.M., \& Huffcutt, A.I. (1997). Psychometric properties of multisource performance ratings: A meta-analysis of subordinate, supervisor, peer, and selfratings. Human Performance, 10, 331-360.

Cortina, J.M., Chen, G., \& Dunlap, W.P. (2001). Testing interaction effects in Lisrel: Examination and illustration of available procedures. Organization Research Methods, 4, 324-360. 
Coyle-Shapiro, J.A.M., \& Conway, N. (2005). Exchange relationships: Examining psychological contracts and perceived organizational support. Journal of Applied Psychology, 90, 774-781.

Davis, M.H., Kraus, L.A., \& Copabianco, S. (2009). Age differences in responses to conflict in the workplace. International Journal of Aging and Human Development, $68,339-355$.

De Lange, A.H., Taris, T.W., Jansen, P., Kompier, M.A.J., Houtman, I.L.D., \& Bongers, P.M. (2010). On the relationships among work characteristics and learning-related behavior: Does age matter? Journal of Organizational Behavior, 31, 925-950.

De Lange, A., Taris, T., Jansen, P., Smulder, P., Houtman, I., \& Kompier, M. (2006). Age as a factor in the relation between work and mental health: Results from the longitudinal TAS survey. In J. Houdmont \& S. McIntyre (Eds.), Occupational health psychology: European perspectives on research, education and practice (Vol. 1, pp. 21-45). Maia, Portugal: ISMAI Publications.

De Lange, A.H., Taris, T.W., Kompier, M.A.J., Houtman, I.L.D., \& Bongers, P.M. (2003). "The very best of the millennium": Longitudinal research and the demand-control-(support) model. Journal of Occupational Health Psychology, 8, 282-305.

De Vos, A., Buyens, D., \& Schalk, R. (2003). Psychological contract development during organizational socialization: Adapting to reality and the role of reciprocity. Journal of Organizational Behavior, 24, 537-559.

Diamond, L.M., \& Aspinwall, L.G. (2003). Emotion regulation across the life span: An integrative perspective emphasizing self-regulation, positive affect, and dyadic processes. Motivation and Emotion, 27, 125-156.

Gross, J.J. (1998). The emerging field of emotion regulation: An integrative review. Review of General Psychology, 2, 271-299.

Gross, J.J. (2001). Emotion regulation in adulthood: Timing is everything. Current Directions in Psychological Science, 10, 214-219.

Gross, J.J., Carstensen, L.L., Pasupathi, M., Tsai, J., Skorpen, C.G., \& Hsu, A.Y.C. (1997). Emotion and aging: Experience, expression, and control. Psychology and Aging, 12, 590-599.

Guest, D.E. (2004). The psychology of the employment relationship: An analysis based on the psychological contract. Applied Psychology: An International Review, $53,541-555$.

Harrison, D.A., Newman, D.A., \& Roth, P.L. (2006). How important are job attitudes? Meta-analytic comparisons of integrative behavioral outcomes and time sequences. Academy of Management Journal, 49, 305-325.

Heckhausen, J., Wrosch, C., \& Schulz, R. (2010). A motivational theory of life-span development. Psychological Review, 117, 32-60.

Hu, L., \& Bentler, P.M. (1999). Cutoff criteria for fit indexes in covariance structure analysis: Conventional criteria versus new alternatives. Structural Equation Modeling, 6, 1-55.

Izard, C.E. (2009). Emotion theory and research: Highlights, unanswered questions, and emerging issues. Annual Review of Psychology, 60, 1-25. 
John, O.P., \& Gross, J.J. (2004). Healthy and unhealthy emotion regulation: Personality processes, individual differences, and life span development. Journal of Personality, 72, 1301-1333.

Jöreskog, K., \& Sörbom, D. (2005). Lisrel 8.72. Chicago, IL: Scientific Software International.

Kanfer, R., \& Ackerman, P.L. (2004). Aging, adult development, and work motivation. Academy of Management Review, 29, 440-458.

Kooij, D., De Lange, A., Jansen, P., \& Dikkers, J. (2008). Older workers' motivation to continue to work: Five meanings of age. Journal of Managerial Psychology, 23, 364-394.

Kooij, D., De Lange, A.H., Jansen, P.G.W., Kanfer, R., \& Dikkers, J. (2011). Age and work-related motives: Results of a meta-analysis. Journal of Organizational Behavior, 32, 197-225.

Kristensen, T.S., Bjorner, J.B., Christensen, K.B., \& Borg, V. (2004). The distinction between working pace and working hours in the measurement of quantitative demands at work. Work \& Stress, 18, 305-322.

Kristensen, T.S., Hannerz, H., Høgh, A., \& Borg, H. (2005). The Copenhagen Psychosocial Questionnaire - a tool for the assessment and improvement of the psychosocial work environment. Scandinavian Journal of Work, Environment, and Health, 31, 438-449.

Kunzmann, U., Kupperbusch, C.S., \& Levenson, R.W. (2005). Behavioral inhibition and amplification during emotional arousal: A comparison of two age groups. Psychology and Aging, 20, 144-158.

Kunzmann, U., \& Richter, D. (2009). Emotional reactivity across the adult life span: The cognitive pragmatics make a difference. Psychology and Aging, 24, 879-889.

Lang, F.R., \& Carstensen, L.L. (2002). Time counts: Future time perspective, goals, and social relationships. Psychology and Aging, 17, 125-139.

Lawton, M.P., Kleban, M.H., Rajagopal, D., \& Dean, J. (1992). Dimensions of affective experience in three age groups. Psychology and Aging, 7, 171-184.

MacCallum, R.C., Browne, M.W., \& Sugawara, H.M. (1996). Power analysis and determination of sample size for covariance structure modeling. Psychological Methods, 1, 130-149.

McClelland, G.H., \& Judd, C.M. (1993). Statistical difficulties of detecting interactions and moderator effects. Psychological Bulletin, 114, 376-390.

Mathieu, J.E., Tannenbaum, S.I., \& Salas, E. (1992). Influences of individual and situational characteristics on measures of training effectiveness. Academy of Management Journal, 35, 828-847.

Maurer, T.J., Weiss, E.M., \& Barbeite, F.G. (2003). A model of involvement in work-related learning and development activity: The effects of individual, situational, motivational, and age-variables. Journal of Applied Psychology, 88, 707724.

Morrison, E.W., \& Robinson, S.L. (1997). When employees feel betrayed: A model of how psychological contract violation develops. Academy of Management Review, 22, 226-256.

$\mathrm{Ng}$, T.W.H., \& Feldman, D.C. (2008). The relationship of age to ten dimensions of job performance. Journal of Applied Psychology, 93, 392-423. 
Ng, T.W.H., \& Feldman, D.C. (2009). Age, work experience, and the psychological contract. Journal of Organizational Behavior, 30, 1053-1075.

Noonan, A.E. (2005). "At this point now": Older workers' reflections on their current employment experiences. International Journal of Aging and Human Development, 61, 211-241.

Peterson, S.J., \& Spiker, B.K. (2005). Establishing the positive contributory value of older workers: A positive psychology perspective. Organizational Dynamics, 34, 153-167.

Podsakoff, P.M., MacKenzie, S.B., Lee, J., \& Podsakoff, N.P. (2003). Common method biases in behavioral research: A critical review of the literature and recommended remedies. Journal of Applied Psychology, 88, 879-903.

Raja, U., Johns, G., \& Ntalianis, F. (2004). The impact of personality on psychological contracts. Academy of Management Journal, 47, 350-367.

Roehling, P.V., Roehling, M.V., \& Moen, P. (2001). The relationship between worklife policies and practices and employee loyalty: A life course perspective. Journal of Family and Economic Issues, 22, 141-170.

Rousseau, D.M. (1995). Psychological contracts in organizations: Understanding written and unwritten agreements. Thousand Oaks, CA: Sage.

Rousseau, D.M., \& Parks, J.M. (1993). The contracts of individuals and organizations. In L.L. Cummings \& B.M. Staw (Eds.), Research in organizational behavior (Vol. 15, pp. 1-43). Greenwich, CT: JAI Press.

Schaie, K.W. (1986). Beyond calendar definitions of age, time, and cohort: The general developmental model revisited. Developmental Review, 6, 252-277.

Smola, K.W., \& Sutton, C.D. (2002). Generational differences: Revisiting generational work values for the new millennium. Journal of Organizational Behavior, 23, 363-382.

Sturman, M.C., Cheramie, R.A., \& Cashen, L.H. (2005). The impact of job complexity and performance measurement on the temporal consistency, stability, and test-retest reliability of employee performance ratings. Journal of Applied Psychology, 90, 269-283.

Suazo, M.M., Martínez, P.G., \& Sandoval, R. (2009). Creating psychological and legal contracts through human resource practices: A signaling theory perspective. Human Resource Management Review, 19, 154-166.

Thoresen, C.J., Kaplan, S.A., Barsky, A.P., Warren, C.R., \& de Chermont, K. (2003). The affective underpinnings of job perceptions and attitudes: A meta-analytic review and integration. Psychological Bulletin, 129, 914-945.

Wagner, S.L., \& Rush, M.C. (2000). Altruistic organizational citizenship behavior: Context, disposition, and age. Journal of Social Psychology, 140, 379-391.

Wall, T.D., Michie, J., Patterson, M., Wood, S.J., Sheehan, M., Clegg, C.W., \& West, M. (2004). On the validity of subjective measures of company performance. Personnel Psychology, 57, 95-118.

Weiss, H.M., \& Cropanzano, R. (1996). Affective Events Theory: A theoretical discussion of the structure, causes and consequences of affective experiences at work. In B.M. Staw \& L.L. Cummings (Eds.), Research in organizational behavior: An annual series of analytical essays and critical reviews (Vol. 18, pp. 1-74). Greenwich, CT: JAI Press. 
Williams, L.J., \& Anderson, S.E. (1991). Job satisfaction and organizational commitment as predictors of organizational citizenship and in-role behaviors. Journal of Management, 17, 601-617.

Wright, T.A., \& Bonett, D.G. (2002). The moderating effects of employee tenure on the relation between organizational commitment and job performance: A metaanalysis. Journal of Applied Psychology, 87, 1183-1190.

Zapf, D., Dormann, C., \& Frese, M. (1996). Longitudinal studies in organizational stress research: A review of the literature with reference to methodological issues. Journal of Occupational Health Psychology, 1, 145-169.

Zhao, H., Wayne, S.J., Glibkowski, B.C., \& Bravo, J. (2007). The impact of psychological contract breach on work-related outcomes: A meta-analysis. Personnel Psychology, 60, 647-680.

\section{APPENDIX}

\section{Results of Scale Analyses using Confirmatory Factor Analysis}

\begin{tabular}{lrcccccc}
\hline Model & \multicolumn{1}{c}{$\chi^{2}$} & $\mathrm{df}$ & $\Delta \chi^{2}$ & $\Delta d f$ & RMSEA & SRMR & CFI \\
\hline 7-factor & $633.28^{* * *}$ & 251 & Baseline Model & & .07 & .06 & .96 \\
8-factor & $622.55^{* * *}$ & 232 & $10.73_{\mathrm{ns}}$ & 19 & .09 & .06 & .96 \\
9-factor & $564.03^{* * *}$ & 198 & $69.25_{\mathrm{ns}}$ & 53 & .08 & .06 & .96 \\
6-factor & $1029.68^{* * *}$ & 257 & $396.40^{* * *}$ & 6 & .11 & .09 & .88 \\
6-factor & $737.01^{* * *}$ & 257 & $103.73^{* * *}$ & 6 & .09 & .07 & .94 \\
5-factor & $1351.77^{* * *}$ & 262 & $718.49^{* * *}$ & 11 & .13 & .13 & .89 \\
3-factor & $1761.81^{* * *}$ & 269 & $1128.53^{* * *}$ & 18 & .15 & .14 & .82 \\
2-factor & $1660.36^{* * *}$ & 271 & $1027.08^{* * *}$ & 20 & .15 & .10 & .79 \\
2-factor & $2578.17^{* * *}$ & 271 & $1944.89^{* * *}$ & 20 & .19 & .24 & .77 \\
1-factor & $2413.02^{* * *}$ & 272 & $1779.74^{* * *}$ & 21 & .18 & .14 & .72 \\
\hline
\end{tabular}

Note: ${ }^{* * *} p<.001$; 7-factor: economic breach, socio-emotional breach, developmental breach, job satisfaction T1, job performance T1, job satisfaction T2, and job performance T2. 8-factor: economic breach, socio-emotional breach, developmental breach, a second-order factor of the three types of psychological contract breach, job satisfaction T1, job performance T1, job satisfaction T2, and job performance $\mathrm{T} 2$. 9-factor: economic breach, socio-emotional breach, developmental breach, a second-order factor of the three types of psychological contract breach, job satisfaction T1, job performance T1, job satisfaction T2, job performance T2, and all items to an unmeasured latent factor. 6-factor ${ }_{\mathrm{a}}$ : economic breach, socio-emotional breach, developmental breach, job satisfaction T1 and T2, job performance T1, and job performance T2. 6-factor : economic breach, socio-emotional breach, developmental breach, job satisfaction T1, job performance T1 and T2, job satisfaction T2. 5-factor: contract breach (economic, socio-emotional, and developmental breach), job satisfaction T1, job performance T1, job satisfaction T2, and job performance T2. 3-factor: contract breach (economic, socio-emotional, and developmental breach), job satisfaction T1 and T2, and job performance T1 and T2. 2-factor ${ }_{\mathrm{a}}$ : contract breach and job satisfaction (economic, socio-emotional, developmental breach, and job satisfaction T1 and T2), and job performance T1 and T2. 2-factor : contract breach (economic, socio-emotional, and developmental breach) and work outcomes (job satisfaction T1 and T2, and job performance T1 and T2). 1-factor: All items loading on one factor.

(C) 2012 The Authors. Applied Psychology: An International Review (C) 2012 International Association of Applied Psychology. 